University of Wollongong

Research Online

Faculty of Engineering and Information

Faculty of Engineering and Information

Sciences - Papers: Part A

Sciences

$1-1-2010$

\title{
Bauschinger effect in microalloyed steels: part I. Dependence on dislocation-particle interaction
}

Andrii Kostryzhev

University of Birmingham, andrii@uow.edu.au

Martin Strangwood

University of Birmingham

Claire L. Davis

University of Birmingham

Follow this and additional works at: https://ro.uow.edu.au/eispapers

Part of the Engineering Commons, and the Science and Technology Studies Commons

Research Online is the open access institutional repository for the University of Wollongong. For further information contact the UOW Library: research-pubs@uow.edu.au 


\title{
Bauschinger effect in microalloyed steels: part I. Dependence on dislocation- particle interaction
}

\author{
Abstract \\ The Bauschinger effect (yield stress decreasing at the start of reverse deformation after forward \\ prestrain) is an important factor in strength development for cold metal forming technology. In steels, the \\ magnitude of the Bauschinger effect depends on composition, through the presence of microalloy \\ precipitates, and prior processing, through the size and distribution of microalloy precipitates and \\ presence of retained work hardening. In this article, the microstructures of two ( $\mathrm{Nb}$ - and Nb-V- \\ microalloyed) steel plates, in terms of ( $\mathrm{Ti}, \mathrm{Nb}, \mathrm{V}, \mathrm{Cu})$-rich particle distributions and dislocation densities, \\ have been quantitatively related to the Bauschinger parameters for the same processing conditions. For \\ the 12- to 50-nm effective particle size range, the Bauschinger stress parameter increases with the \\ particle number density and dislocation density increase. The relative influence of these two \\ microstructure parameters is discussed.

\section{Keywords} \\ effect, microalloyed, steels, part, i, dependence, dislocation, particle, bauschinger, interaction

\section{Disciplines} \\ Engineering | Science and Technology Studies

\section{Publication Details} \\ Kostryzhev, A. G., Strangwood, M. \& Davis, C. L. (2010). Bauschinger effect in microalloyed steels: part I. \\ Dependence on dislocation-particle interaction. Metallurgical and Materials Transactions A: Physical \\ Metallurgy and Materials Science, 41 (6), 1399-1408.
}




\title{
Bauschinger Effect in Microalloyed Steels: Part I. Dependence on Dislocation-Particle Interaction
}

\begin{abstract}
ANDRII G. KOSTRYZHEV, MARTIN STRANGWOOD, and CLAIRE L. DAVIS
The Bauschinger effect (yield stress decreasing at the start of reverse deformation after forward prestrain) is an important factor in strength development for cold metal forming technology. In steels, the magnitude of the Bauschinger effect depends on composition, through the presence of microalloy precipitates, and prior processing, through the size and distribution of microalloy precipitates and presence of retained work hardening. In this article, the microstructures of two ( $\mathrm{Nb}$ - and $\mathrm{Nb}$ - $\mathrm{V}$-microalloyed) steel plates, in terms of ( $\mathrm{Ti}, \mathrm{Nb}, \mathrm{V}, \mathrm{Cu})$-rich particle distributions and dislocation densities, have been quantitatively related to the Bauschinger parameters for the same processing conditions. For the 12- to 50-nm effective particle size range, the Bauschinger stress parameter increases with the particle number density and dislocation density increase. The relative influence of these two microstructure parameters is discussed.
\end{abstract}

DOI: 10.1007/s11661-010-0196-4

(c) The Minerals, Metals \& Materials Society and ASM International 2010

\section{INTRODUCTION}

THERE are two principal Bauschinger effect theories (Figure 1): back stress and Orowan theory. ${ }^{[1,2]}$ During forward plastic deformation, moving dislocations interact with different obstacles (e.g., other dislocations, grain boundaries, and precipitates), preventing their further propagation. This generates a back stress around the contact point resisting further progress of dislocations. During reverse deformation, this back stress repels the dislocations from the obstacles in the opposite direction, namely in the direction of reverse strain. Thus, the stress field helps to move the dislocations in the direction of reverse strain and the reverse yield stress drops by the level of the back stress. Material with a larger number of dislocations (rolled below the recrystallization stop temperature) and obstacles (precipitates) will show a larger yield drop after reverse cold deformation due to the presence of a larger number density of dislocation-obstacle interaction sites.

Experimental investigations have shown that, in microalloyed steels, the Bauschinger effect does not depend on grain size, ${ }^{[3]}$ but depends on steel chemistry ${ }^{[-7]}$ and phase balance. ${ }^{[8]}$ Recent research has shown a Bauschinger effect dependence on microalloying element particles $^{[9]}$ and dislocation structure: ${ }^{[10]}$ with an increase in particle volume fraction and dislocation density, the yield stress drop in the direction of reverse strain increases. To predict the strength change, in practice, one needs a quantitative model of dislocation-particle

ANDRII G. KOSTRYZHEV, Research Fellow, School of Electronic, Electrical and Computer Engineering, MARTIN STRANGWOOD, Senior Lecturer, and CLAIRE L. DAVIS, Professor of Ferrous Metallurgy, are with the School of Metallurgy and Materials, University of Birmingham, Edgbaston, Birmingham, B15 2TT, United Kingdom. Contact e-mail: kostryzhev@yahoo.com

Manuscript submitted August 16, 2009.

Article published online March 18, 2010 interaction influence on the yield stress. This is discussed in the present article.

\section{MATERIALS}

For the investigation, two microalloyed steels with a banded ferrite-pearlite microstructure in as-rolled and annealed conditions were used. Annealing at $400{ }^{\circ} \mathrm{C}$ and $550{ }^{\circ} \mathrm{C}$ for 30 minutes was applied to modify the dislocation structure and microalloying element particle distributions, without affecting the grain size and the second-phase content. Original steel plates of $10-\mathrm{mm}$ thickness were provided by Corus plc (Table I). Optical microscopy of the as-rolled steel plates has shown the grain size to be 2.0 to $3.0 \mu \mathrm{m}$ in both studied steels and the second-phase content to decrease from 9.5 pct in the $\mathrm{C}-\mathrm{Nb}$ to $4.6 \mathrm{pct}$ in the $\mathrm{C}-\mathrm{Nb}-\mathrm{V}$ steel, due to decreasing carbon content in steel composition. ${ }^{[9,10]}$

\section{EXPERIMENTAL TECHNIQUES}

Thermodynamic modeling of the steel microstructures was carried out using version L of Thermo-Calc (Royal Institute of Technology, Stockholm, Sweden) with the bulk alloy composition as an input. Equilibrium phase balances within the temperature range 600 to $1600 \mathrm{~K}$ were calculated along with phase compositions.

Scanning electron microscopy (SEM) was carried out using a JEOL* JSM-7000F field emission gun-scanning

*JEOL is a trademark of Japan Electron Optics Ltd., Tokyo.

electron microscope. $\mathrm{Nb}$ - and $\mathrm{Nb}$-Ti-rich precipitates were imaged from four regions, ferrite and pearlite, subsurface, and midthickness, and characterized in terms of size, morphology, and area fraction. For the 
determination of the particle size distributions and area fraction in the C-Nb steel, 630 particles from $15,585 \mu \mathrm{m}^{2}$ and in the $\mathrm{C}-\mathrm{Nb}-\mathrm{V}$ steel 1064 particles from a total area of $10,780 \mu \mathrm{m}^{2}$ were imaged.

Transmission electron microscopy was carried out on PHILIPS**-CM20 $\left(\mathrm{LaB}_{6}\right)$ and PHILIPS Tecnai

**PHILIPS is a trademark of FEI Company, Hillsboro, OR.

F20 (field emission gun) transmission electron microscopes. ( Nb, Ti, V,Cu)-rich particles in the C-Nb-V steel were imaged from two regions, plate midthickness and subsurface. For the determination of the particle size distributions and volume fraction 1387 particles from $7.03 \mu \mathrm{m}^{2}$ in $\mathrm{C}-\mathrm{Nb}-\mathrm{V}$ as-rolled steel and 688 particles
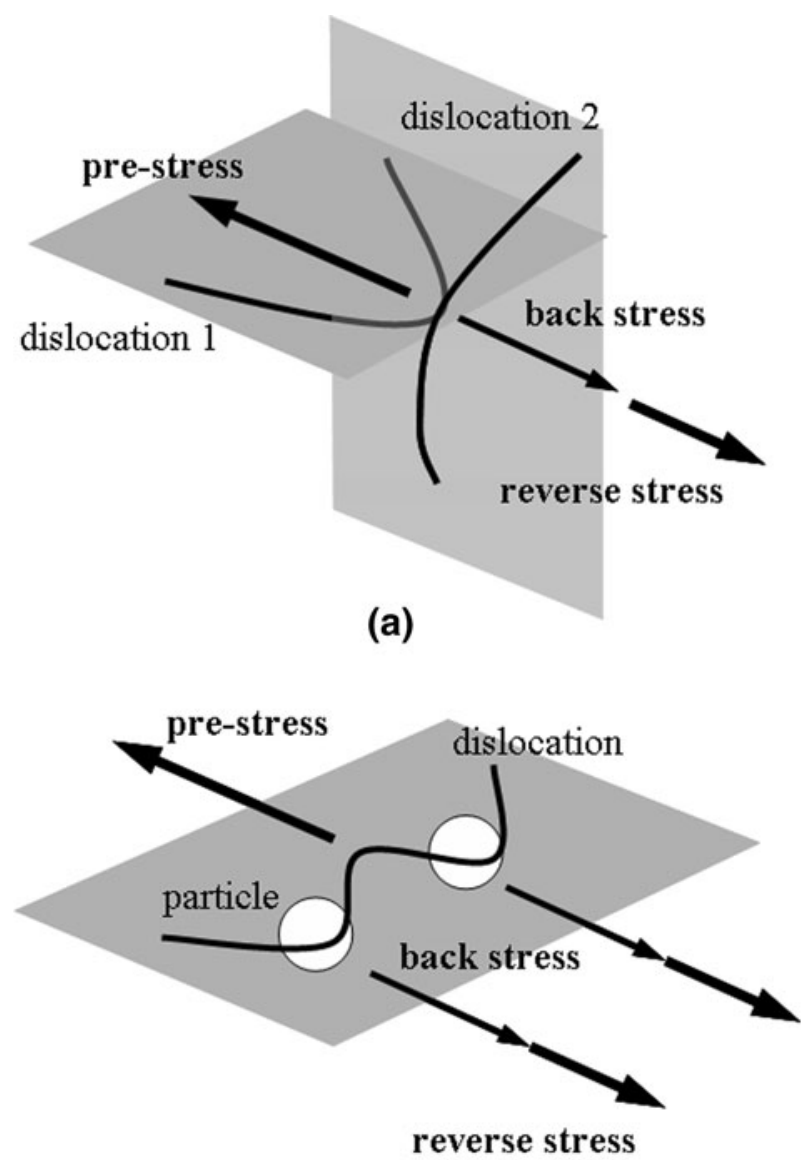

(b)

Fig. 1-Schematic diagram of (a) dislocation-dislocation and (b) dislocation-particle interactions. from $3.35 \mu \mathrm{m}^{2}$ in the $\mathrm{C}-\mathrm{Nb}-\mathrm{V}$ annealed steel were imaged. Foil thickness was determined using a convergent beam diffraction technique. ${ }^{[1]}$

Precipitate compositions were determined using energy dispersive $X$-ray spectroscopy (EDS) point analysis in the JEOL-7000F scanning electron microscope (Inca Oxford energy dispersive X-ray spectroscope), PHILIPS-CM20 transmission electron microscope (Link Oxford energy dispersive X-ray spectroscope), and PHILIPS Tecnai F20 (ISIS Oxford). For the Ti-, $\mathrm{Nb}-, \mathrm{V}-$, and $\mathrm{Cu}$-rich precipitate chemical composition investigation 54 particles in the $\mathrm{C}-\mathrm{Nb}$ and 65 particles in the $\mathrm{C}-\mathrm{Nb}-\mathrm{V}$ steel were used.

Dislocation substructures were studied using PHILIPS-CM20 and PHILIPS Tecnai F20 transmission electron microscopes. For the dislocation density determination, 20 representative regions were imaged in each of the as-rolled and annealed $\mathrm{C}-\mathrm{Nb}$ and $\mathrm{C}-\mathrm{Nb}-\mathrm{V}$ steels from the plate midthickness position. The midthickness position was selected to correlate dislocation density with mechanical property data obtained from the compression-tension samples.

Compression-tension testing was carried out on an ESH $250 \mathrm{kN}$ servo-hydraulic twin column low speed ramp universal testing machine. For the stress-strain curve determination, four cylindrical specimens of 4.5-mm diameter and 13-mm gage length were cut in the transverse orientation to the rolling direction from the $\mathrm{C}-\mathrm{Nb}$ and $\mathrm{C}-\mathrm{Nb}-\mathrm{V}$ as-rolled and annealed steel plates.

\section{RESULTS}

\section{A. Precipitates of Microalloying Elements}

\section{SEM study}

SEM EDS of the precipitated particles in both steels revealed these to be $\mathrm{Nb}$ rich and $\mathrm{Nb}-\mathrm{Ti}$ rich, which corresponds to Thermo-Calc predictions (Figure 2). Because it was not possible to separate $\mathrm{Nb}$ and $\mathrm{Nb}-\mathrm{Ti}$ particle distributions, their average diameter, area fraction, and number density were calculated together. For the number of particles measured in this work, the area fraction can be considered equal to the volume fraction and compared with the Thermo-Calc theoretical prediction. Measurements were carried out separately for ferrite (predominantly ferrite grains) and pearlite (predominantly pearlite colonies) regions. Because a ferrite region band is approximately 2 times broader than a pearlite region band, average plate subsurface and midthickness values of precipitate characteristics were calculated as follows:

average $=(1 \times$ pearlite-region $+2 \times$ ferrite-region $) / 3$

Table I. Plate Composition in Weight Percent

\begin{tabular}{lccccccccccccc}
\hline Steel Grade & $\mathrm{C}$ & $\mathrm{Si}$ & $\mathrm{Mn}$ & $\mathrm{P}$ & $\mathrm{S}$ & $\mathrm{Cr}$ & $\mathrm{Ni}$ & $\mathrm{Cu}$ & $\mathrm{Nb}$ & $\mathrm{V}$ & $\mathrm{N}$ & $\mathrm{Ti}$ & $\mathrm{Mo}$ \\
\hline $\mathrm{C}-\mathrm{Nb}$ & 0.10 & 0.37 & 1.36 & 0.012 & 0.006 & 0.017 & 0.016 & 0.009 & 0.034 & 0.001 & 0.002 & 0.001 & 0.002 \\
$\mathrm{C}-\mathrm{Nb}-\mathrm{V}$ & 0.07 & 0.34 & 1.47 & 0.012 & 0.003 & 0.013 & 0.021 & 0.015 & 0.046 & 0.061 & 0.004 & 0.002 & 0.002 \\
\hline
\end{tabular}




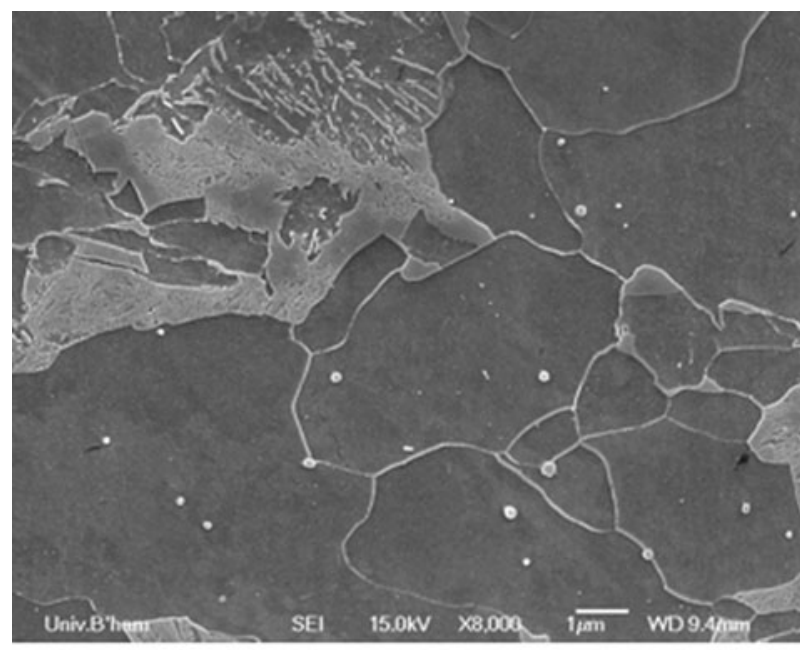

(a)

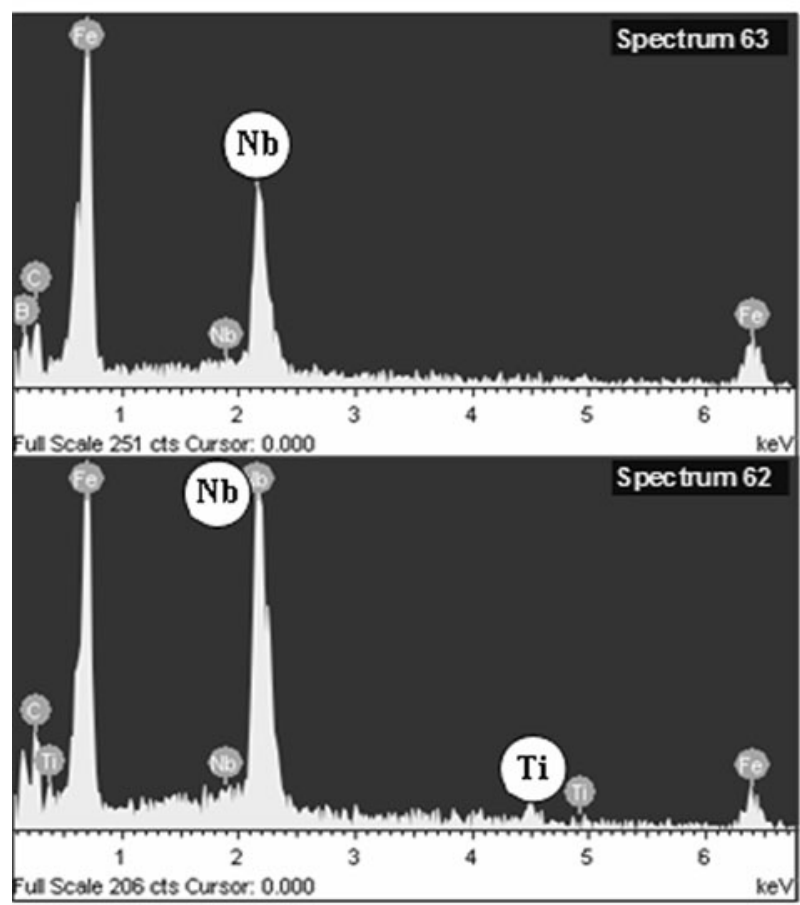

(b)

Fig. 2-(a) SEM image from the C-Nb-V steel midthickness pearlite region and $(b)$ EDS spectra of microalloying element particles.
Analysis of the obtained results (Table II) shows the volume fraction in the pearlite region to be larger than that in the ferrite region due to microsegregation, which is consistent with previous research. ${ }^{[12]}$ Average particle diameter, volume fraction, and number density in the $\mathrm{C}-\mathrm{Nb}$ steel increase toward the midthickness of the plates, which corresponds to the $\mathrm{Nb}$ macrosegregation behavior observed in microalloyed steels. ${ }^{[13]}$ However, in the $\mathrm{C}-\mathrm{Nb}-\mathrm{V}$ steel, no significant difference in average particle diameter and volume fraction was observed between the subsurface and midthickness, and the number density decreases toward the plate midthickness. Particle volume fraction increases with the increase in microalloying element content, as was predicted by Thermo-Calc. The smaller Nb-rich particle diameter observed in the $\mathrm{C}-\mathrm{Nb}-\mathrm{V}$ steel can be explained by the processing variable differences, namely lower finish roll temperature for the $\mathrm{C}-\mathrm{Nb}-\mathrm{V}$ steel $\left(735^{\circ} \mathrm{C}\right)$ than for the $\mathrm{C}-\mathrm{Nb}$ steel $\left(745^{\circ} \mathrm{C}\right)$, leading to a higher dislocation density and more strain-induced precipitation. The measured value for the particle volume fraction in the $\mathrm{C}-\mathrm{Nb}-\mathrm{V}$ steel is significantly lower than predicted by Thermo-Calc, because SEM measurements do not take into account many fine $\mathrm{V}-\mathrm{Cu}-$-rich precipitates. These were studied with transmission electron microscopy (TEM).

\section{TEM study}

TEM investigation was carried out for both $\mathrm{C}-\mathrm{Nb}$ and $\mathrm{C}-\mathrm{Nb}-\mathrm{V}$ steels in as-rolled and annealed conditions. Annealing at $400{ }^{\circ} \mathrm{C}$ and $550{ }^{\circ} \mathrm{C}$ for 30 minutes with further air cooling was carried out to modify the dislocation structure and particle distributions. However, this heat-treatment schedule did not influence the particle distributions in the $\mathrm{C}-\mathrm{Nb}$ steel (Figure 3), which corresponds to the reported stability in ferrite ${ }^{[14]}$ and Thermo-Calc predicted stability of $\mathrm{NbC}$ below $680{ }^{\circ} \mathrm{C}$. In the $\mathrm{C}-\mathrm{Nb}-\mathrm{V}$ steel, particle growth and precipitation of new small particles was observed as a result of annealing (Figure 4). TEM EDS study of the particles smaller than $50 \mathrm{~nm}$ in the $\mathrm{C}-\mathrm{Nb}-\mathrm{V}$ steel revealed these to be $(\mathrm{Ti}, \mathrm{Nb}, \mathrm{V})$ rich, mainly at the plate subsurface, and $\mathrm{Cu}$ rich, mainly at the plate midthickness (Figure 5). Because it was difficult to separate particle distributions for different chemistries, particle parameters were calculated together (Table III).

Table II. Larger Than 50 nm Nb-Ti-Rich Particle Characteristics Measured Using SEM

\begin{tabular}{|c|c|c|c|c|c|c|c|c|c|c|c|c|c|}
\hline \multirow{3}{*}{\multicolumn{2}{|c|}{ Area of precipitation }} & & & & & \multicolumn{4}{|c|}{ Volume Fraction } & & & & \\
\hline & & \multicolumn{4}{|c|}{ Average Diameter, nm } & \multicolumn{2}{|c|}{$\mathrm{C}-\mathrm{Nb}$} & \multicolumn{2}{|c|}{$\mathrm{C}-\mathrm{Nb}-\mathrm{V}$} & \multicolumn{4}{|c|}{ Number Density, $\mu \mathrm{m}^{-3}$} \\
\hline & & \multicolumn{2}{|c|}{$\mathrm{C}-\mathrm{Nb}$} & \multicolumn{2}{|c|}{$\mathrm{C}-\mathrm{Nb}-\mathrm{V}$} & \multicolumn{2}{|c|}{$* f_{\mathrm{TC}}=0.000365$} & \multicolumn{2}{|c|}{$* f_{\mathrm{TC}}=0.001445$} & \multicolumn{2}{|c|}{$\mathrm{C}-\mathrm{Nb}$} & \multicolumn{2}{|c|}{$\mathrm{C}-\mathrm{Nb}-\mathrm{V}$} \\
\hline \multirow[t]{2}{*}{ Sub-surface } & ferrite & 88 & 89 & 67 & 68 & $4.4 \cdot 10^{-5}$ & $6 \cdot 10^{-5}$ & 0.000372 & $4.07 \cdot 10^{-4}$ & 0.12 & 0.16 & 2.36 & 2.42 \\
\hline & pearlite & 90 & & 71 & & $9.7 \cdot 10^{-5}$ & & 0.000476 & & 0.25 & & 2.54 & \\
\hline \multirow[t]{2}{*}{ Mid-thickness } & ferrite & 132 & 131 & 58 & 68 & $6.7 \cdot 10^{-5}$ & $5 \cdot 10^{-4}$ & 0.000165 & $4.22 \cdot 10^{-4}$ & 0.06 & 0.44 & 1.61 & 1.95 \\
\hline & pearlite & 128 & & 88 & & 0.001325 & & 0.000937 & & 1.21 & & 2.63 & \\
\hline
\end{tabular}

${ }^{*} f_{\mathrm{TC}}=$ total particle volume fraction calculated with Thermo-Calc. 

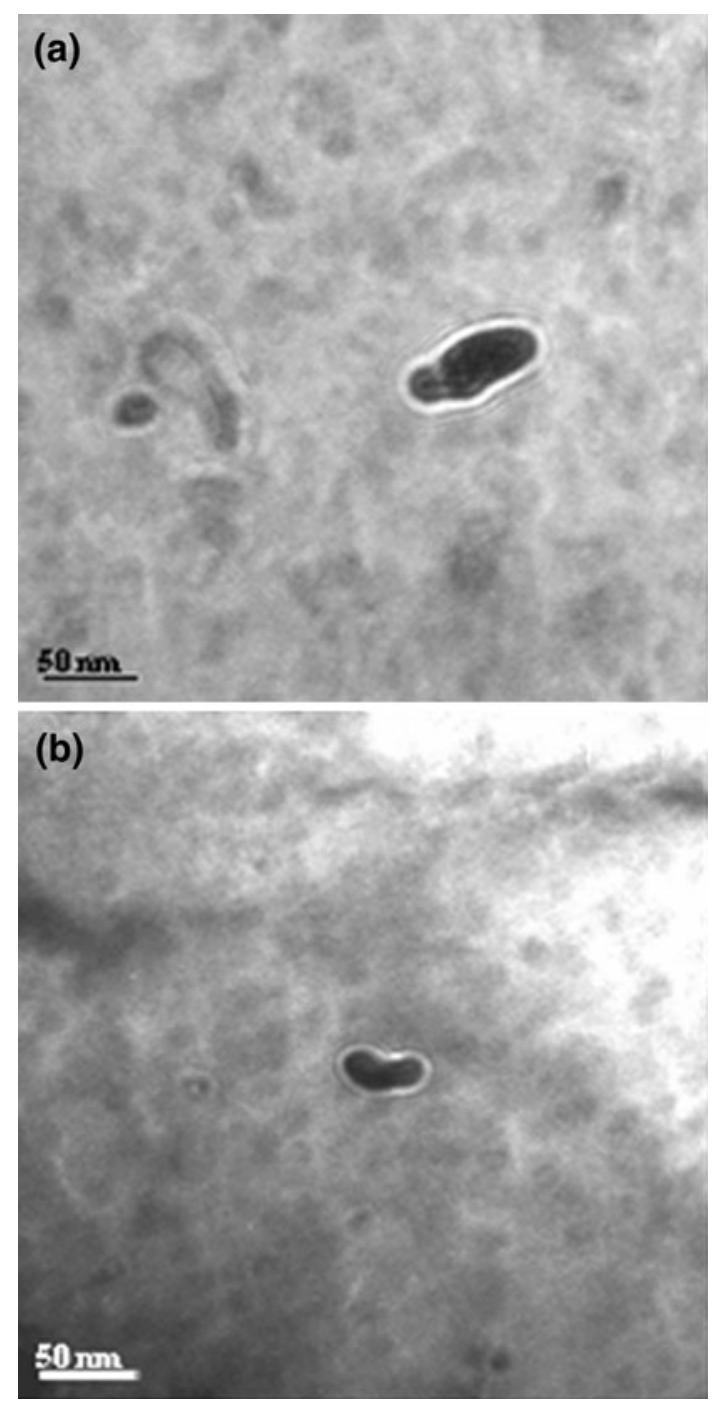

Fig. 3-Selected TEM images (slightly defocused to increase contrast) from the $\mathrm{C}-\mathrm{Nb}$ steel plate midthickness showing $\mathrm{Nb}$-rich particles: (a) as-rolled and $(b)$ annealed at $550{ }^{\circ} \mathrm{C}$ for $30 \mathrm{~min}$.

In the as-rolled $\mathrm{C}-\mathrm{Nb}-\mathrm{V}$ steel, the particle diameter decrease and number density increase toward midthickness can be explained by the particle chemistry difference: as $\mathrm{Cu}$-rich particles precipitate at lower temperatures than $\mathrm{Nb}-\mathrm{V}$-rich ones, these have less time for growth. An increased particle number density at the midthickness may also be expected due to strain-induced precipitation, ${ }^{[15-17]}$ as the dislocation density at the midthickness was observed to be 3.3 times higher than that at the subsurface. At the midthickness position, the $\mathrm{Cu}$-rich particle diameter increases with annealing due to particle growth (Figure 6). The particle number density increase at $400{ }^{\circ} \mathrm{C}$ and decrease at $550{ }^{\circ} \mathrm{C}$ can be explained by precipitation of new $\mathrm{Cu}$-rich particles during the first stages of annealing followed by the particle growth via absorption of smaller ones. The particle number density increase and the average diameter decrease at the subsurface position can be related to the new $\mathrm{Cu}$-rich particles that precipitate. This corresponds to reported time-dependent $\mathrm{Cu}$-rich particle behavior during annealing at 450 to $500{ }^{\circ} \mathrm{C} .{ }^{[18,19]}$

\section{B. Dislocation Density}

Thin foil TEM imaging of both steels in as-rolled and annealed conditions revealed an irregular dislocation structure with uniform dislocation density (Figure 7). Regular straight line structure, clusters, net arrangements, and start-up of cell walls were also observed in some grains. Due to the lower finish rolling temperature, the dislocation density in the $\mathrm{C}-\mathrm{Nb}-\mathrm{V}$ steel was higher than in the $\mathrm{C}-\mathrm{Nb}$ steel (Table IV). Annealing leads to a dislocation density decrease due to annihilation. Absolute values of the dislocation density are in good agreement with the reported data for hot-rolled low carbon steels ${ }^{[20,21]}$ and TMCR-processed X80 steel. ${ }^{[22]}$

\section{Mechanical Properties}

Mechanical properties of both steels were studied in the as-rolled and annealed conditions, during forward and reverse loading (Figure 8). The $\mathrm{C}-\mathrm{Nb}-\mathrm{V}$ steel showed higher macrohardness and compression yield stress than the $\mathrm{C}-\mathrm{Nb}$ steel, due to the larger secondphase content, dislocation density, and precipitate number density (Table V). However, an 8.3 pct increase in hardness and 1.5 pct increase in the yield stress from the $\mathrm{C}-\mathrm{Nb}$ as-rolled to the $\mathrm{C}-\mathrm{Nb}-\mathrm{V}$ as-rolled steel appear to be inconsistent with 45 times particle number density and 1.7 times dislocation density increase. This could be explained if small coherent $(\mathrm{Cu}, \mathrm{V})$-rich particles, in the diameter range below $50 \mathrm{~nm}$, did not pin the dislocations strongly enough to increase the yield stress.

In the $\mathrm{C}-\mathrm{Nb}$ steel, the yield stress and hardness decreased after annealing, but not to any major extent. In the $\mathrm{C}-\mathrm{Nb}$ steel, where particle number density is relatively low and dislocation-dislocation interaction is the main source of work hardening, obviously, not all the dislocations interact with obstacles and grain refinement is the major strengthening mechanism. However, the annealing schedule was chosen not to affect the grain size.

In the $\mathrm{C}-\mathrm{Nb}-\mathrm{V}$ steel, hardness decreased and the yield stress slightly increased after annealing. Obviously, in this steel, two concurrent processes occur during annealing: dislocation annihilation (leading to the number of dislocation-obstacle interaction sites decreasing) and $(\mathrm{Cu}, \mathrm{V})$-rich particle growth and precipitation of new $\mathrm{Cu}$-rich particles (leading to the number of dislocation-obstacle interaction sites increasing). An increase in the yield stress can be qualitatively related to the 2.2 times increase in the particle number density from the $\mathrm{C}-\mathrm{Nb}-\mathrm{V}$ as rolled to the $\mathrm{C}-\mathrm{Nb}-\mathrm{V}$ annealed at $400{ }^{\circ} \mathrm{C}$ (Table V). However, annealing at $550{ }^{\circ} \mathrm{C}$ resulted in the particle number density decreasing, by 2.7 times compared to the asrolled condition, and the yield stress increasing, by $12 \mathrm{MPa}$. This can be attributed to unequal particle ability for pinning of dislocations. Obviously, with particle growth due to an increase in annealing 

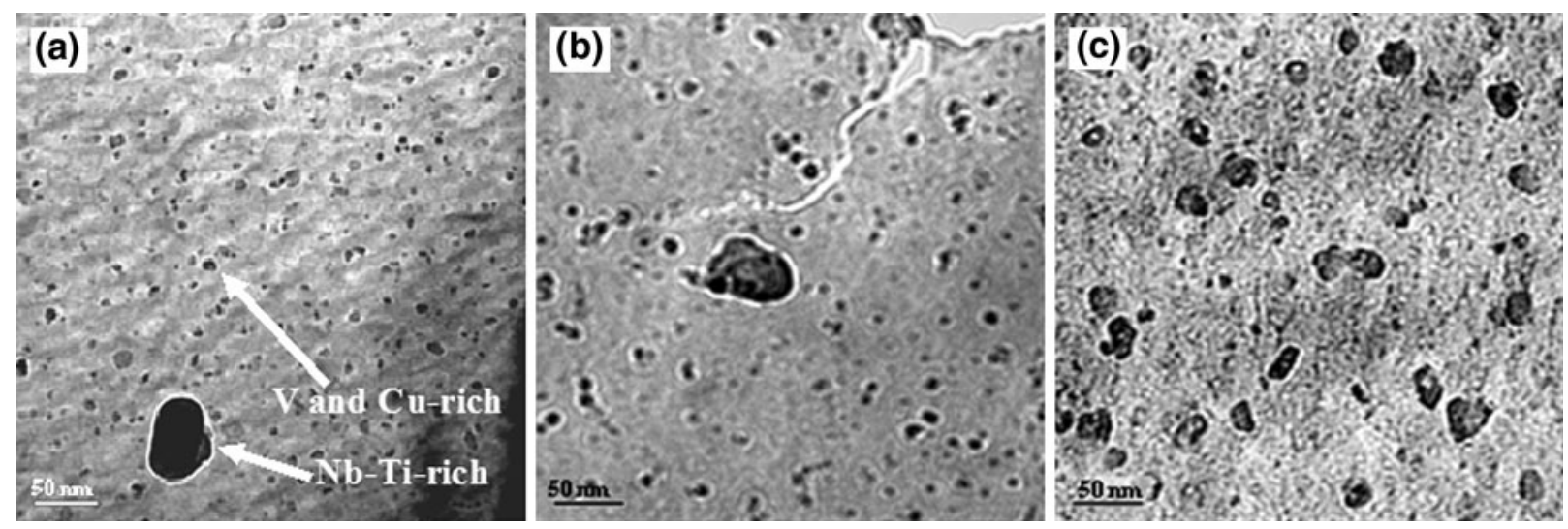

Fig. 4-Typical TEM images from the C-Nb-V steel plate midthickness: (a) as-rolled, (b) annealed at $400{ }^{\circ} \mathrm{C}$ for 30 min, and $(c)$ annealed at $550{ }^{\circ} \mathrm{C}$ for $30 \mathrm{~min}$.

Full scale $=8 \mathrm{cps}$

Cursor: $12.8475 \mathrm{keV}$

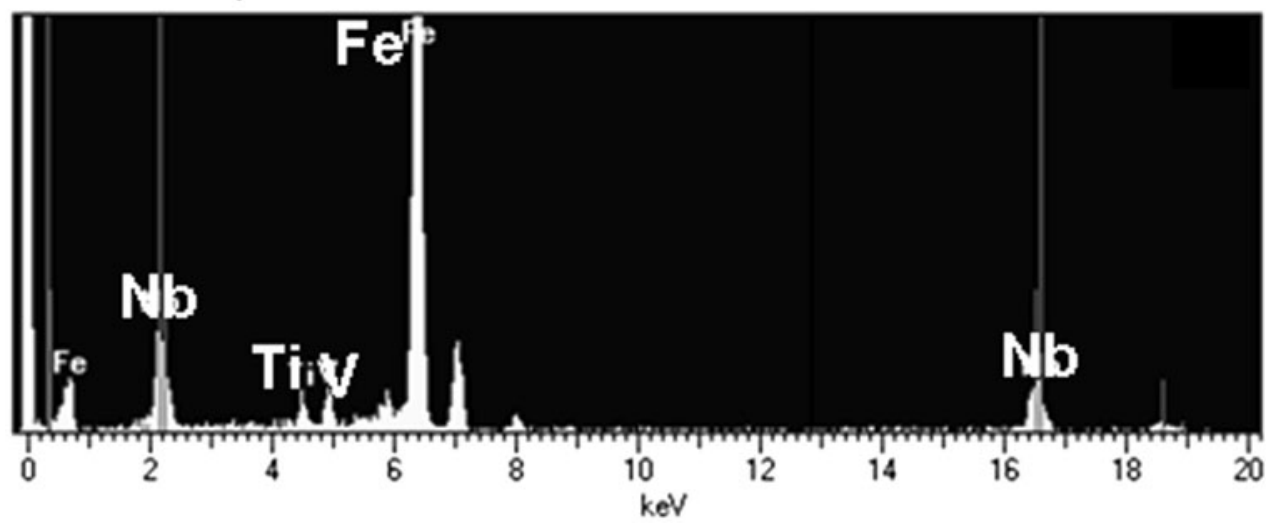

(a)

Full scale $=3 \mathrm{cps}$

Cursor: $0.9275 \mathrm{keV}$

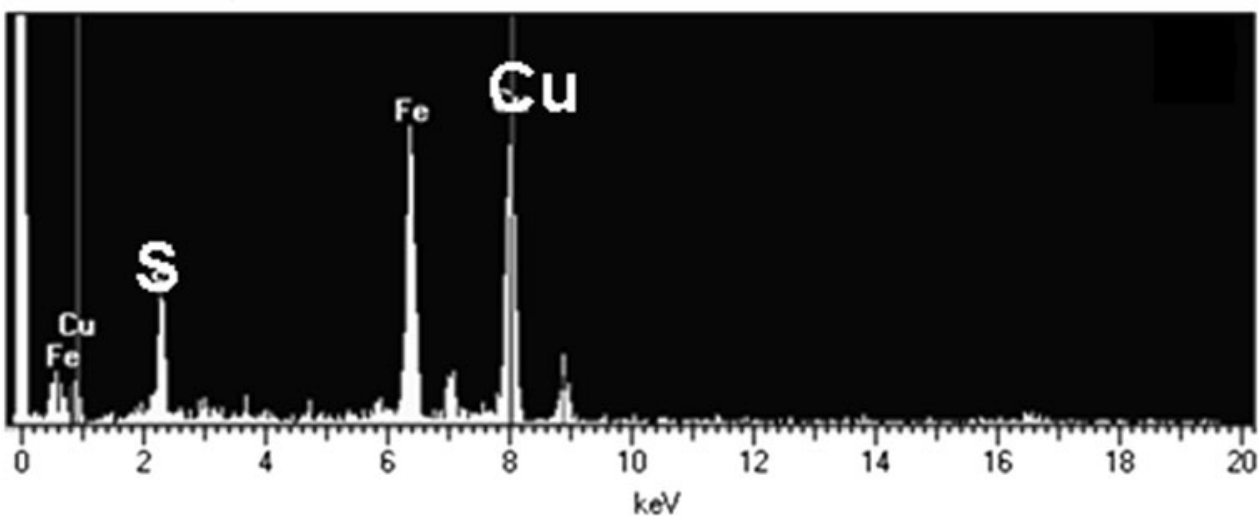

(b)

Fig. 5-Typical EDS spectra of (a) NbTiV-rich and (b) CuS particles in the C-Nb-V steel.

temperature, the number of particles that effectively block the dislocations increases, although the total particle number density decreases.

The yield stress change during deformation in the reverse direction was assessed using the Bauschinger stress parameter ${ }^{[23]}$ (Figures 8 and 9):

$$
\beta_{\sigma}=\frac{\sigma_{p}-\sigma_{r}}{\sigma_{p}}
$$

where $\sigma_{p}$ is the maximum prestress in the forward direction and $\sigma_{r}$ is the yield stress in the reverse direction taken at the point where the stress-strain curve deviates 
Table III. Smaller than 50 nm (Cu + NbTiV)-Rich Particle Characteristics Measured with TEM

\begin{tabular}{|c|c|c|c|c|c|c|c|}
\hline \multirow[b]{3}{*}{ Parameter } & \multirow{3}{*}{$\begin{array}{c}\mathrm{C}-\mathrm{Nb} \\
\begin{array}{c}\text { As-Rolled } \\
\mathrm{m}-\mathrm{t}^{*}\end{array}\end{array}$} & \multicolumn{6}{|c|}{$\mathrm{C}-\mathrm{Nb}-\mathrm{V}$} \\
\hline & & \multicolumn{2}{|c|}{ As-Rolled } & \multicolumn{2}{|c|}{ Annealed $400{ }^{\circ} \mathrm{C}$} & \multicolumn{2}{|c|}{ Annealed $550{ }^{\circ} \mathrm{C}$} \\
\hline & & s-s* & $\mathrm{m}-\mathrm{t}$ & s-s & $\mathrm{m}-\mathrm{t}$ & s-s & $\mathrm{m}-\mathrm{t}$ \\
\hline Predominant chemistry & $\mathrm{NbTi}$ & NbTiV & $\mathrm{Cu}$ & Not measured & $\mathrm{Cu}$ & $\mathrm{NbTiV}+\mathrm{Cu}$ & $\mathrm{Cu}$ \\
\hline Average diameter, $\mathrm{nm}$ & 12.2 & 8.5 & 6.2 & & 7.1 & 7.1 & 16.3 \\
\hline Volume fraction & 0.00012 & 0.00166 & 0.00118 & & 0.00210 & 0.00125 & 0.00384 \\
\hline Number density, $\mu \mathrm{m}^{-3}$ & 86 & 1579 & 3856 & & 8619 & 5075 & 1419 \\
\hline
\end{tabular}

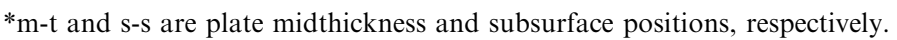

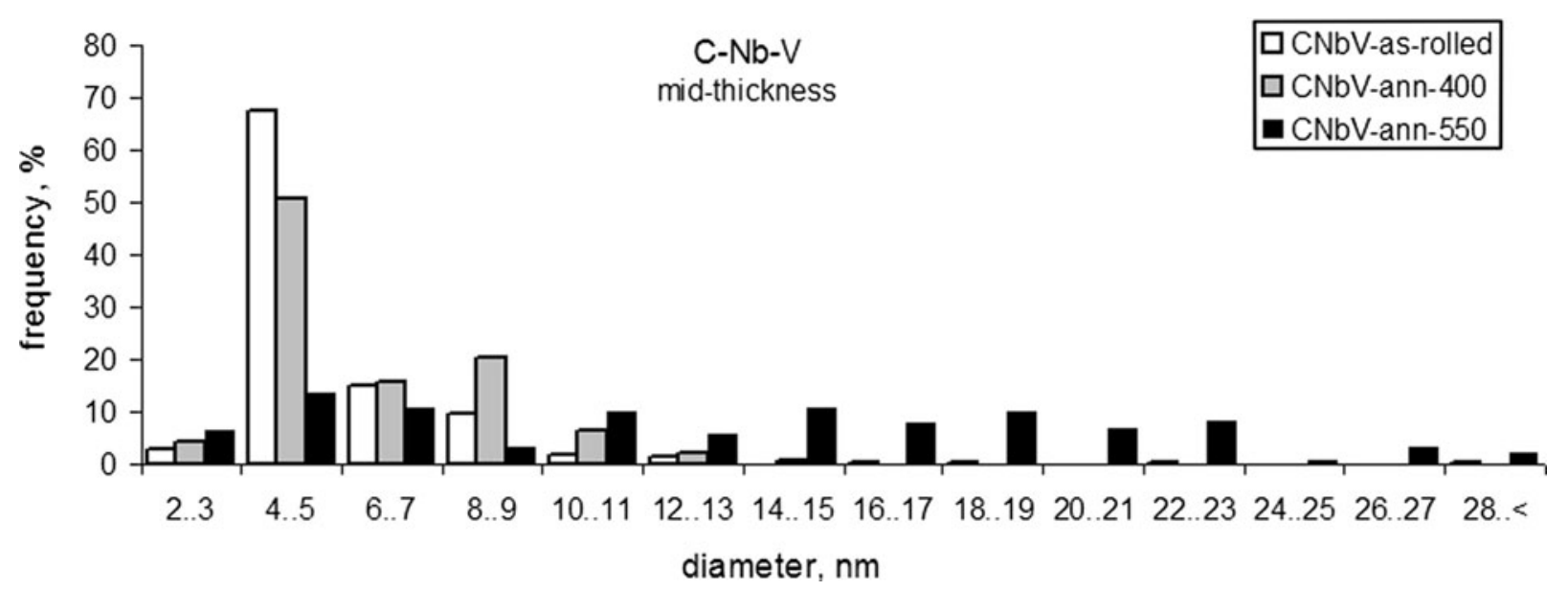

Fig. $6-(\mathrm{Cu}+\mathrm{NbTiV})$-rich particle diameter distributions at the midthickness positions of the as-rolled and annealed $\mathrm{C}-\mathrm{Nb}-\mathrm{V}$ steel plates.

from the elastic deformation straight line (approximately 0.1 pet strain).

The Bauschinger stress parameter increases as a result of the dislocation density increasing

(1) with an increase in forward prestrain,

(2) with an increase in initial work hardening (compare the $\mathrm{C}-\mathrm{Nb}$ and $\mathrm{C}-\mathrm{Nb}-\mathrm{V}$ steels in as-rolled condition), and

(3) from the annealed to as-rolled condition (compare the $\mathrm{C}-\mathrm{Nb}$ steel annealed at $550{ }^{\circ} \mathrm{C}$ and as rolled and the $\mathrm{C}-\mathrm{Nb}-\mathrm{V}$ steel annealed at $400{ }^{\circ} \mathrm{C}$ and as-rolled conditions); and as a result of the particle number density increasing

- with an increase in microalloying element content (compare the $\mathrm{C}-\mathrm{Nb}$ and $\mathrm{C}-\mathrm{Nb}-\mathrm{V}$ steels in as-rolled condition).

Qualitatively, this corresponds to the back stress and Orowan theories of the Bauschinger effect, ${ }^{[1,2]}$ according to which an increase in the number density of dislocation-obstacle interaction sites results in the back stress increasing leading to the yield stress drop in the reverse direction increasing.

However,

(1) a qualitative decrease in particle number density, from the $\mathrm{C}-\mathrm{Nb}-\mathrm{V}$ steel annealed at $400{ }^{\circ} \mathrm{C}$ to annealed at $550{ }^{\circ} \mathrm{C}$, led to the Bauschinger stress parameter increase, at approximately the same level of dislocation density;

(2) a quantitative increase in the Bauschinger stress parameter of 4 to 8 pct from the $\mathrm{C}-\mathrm{Nb}-\mathrm{V}$ annealed at $550{ }^{\circ} \mathrm{C}$ to the $\mathrm{C}-\mathrm{Nb}-\mathrm{V}$ as-rolled is inconsistent with 2.7 times increase in particle number density and 2.7 times increase in dislocation density; and

(3) a quantitative increase in the Bauschinger stress parameter of 7 to 9 pct from the $\mathrm{C}-\mathrm{Nb}$ as-rolled to the $\mathrm{C}-\mathrm{Nb}-\mathrm{V}$ as-rolled steel is inconsistent with 45 times increase in particle number density and 1.7 times increase in dislocation density.

These factors are discussed in Section V.

\section{DISCUSSION}

In order to determine why the trends in the Bauschinger stress parameter with respect to dislocation density and particle number density changes were not always as expected, a more detailed study of the dislocation-particle interaction was carried out. TEM image analysis of 45 dislocation-particle interaction sites in the $\mathrm{C}-\mathrm{Nb}$ and $\mathrm{C}-\mathrm{Nb}-\mathrm{V}$ steels showed the following.

(1) Dislocation loops around particles were not observed, which supports a cutting interaction mechanism. 

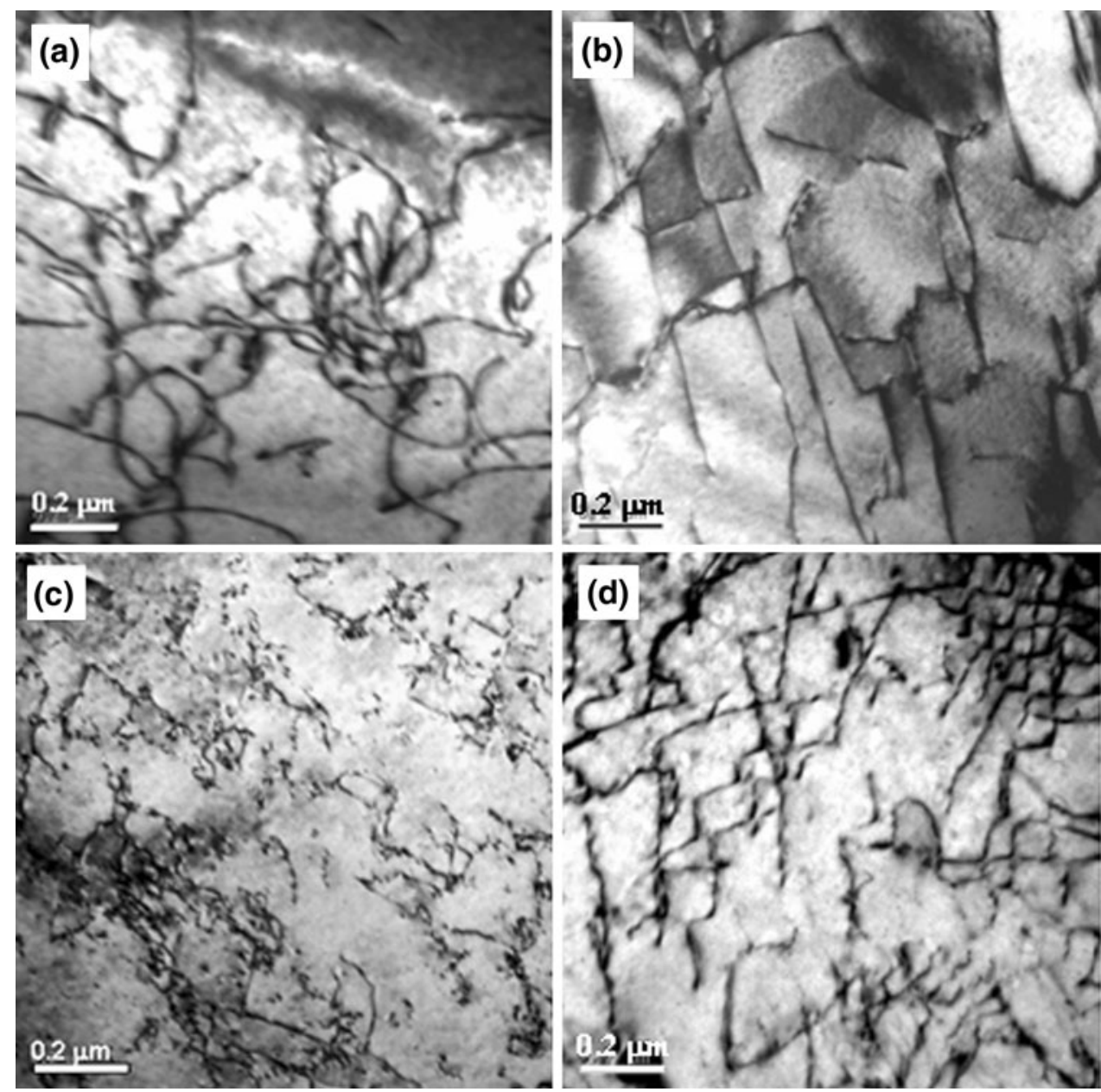

Fig. 7-Typical TEM images of dislocation structure in the C-Nb $(a)$ as-rolled and $(b)$ annealed and C-Nb-V and $(c)$ as-rolled and $(d)$ annealed steels.

Table IV. Dislocation Density at Plate Midthickness Position, $\times 10^{14} \mathrm{~m}^{-2}$

\begin{tabular}{llccc}
\hline Steel & \multicolumn{1}{c}{ Condition } & Minimum & Maximum & Average \\
\hline $\mathrm{C}-\mathrm{Nb}$ & as-rolled & 1.9 & 3.1 & 2.3 \\
& annealed $550{ }^{\circ} \mathrm{C}$ & 0.8 & 2.0 & 1.1 \\
$\mathrm{C}-\mathrm{Nb}-\mathrm{V}$ & as-rolled & 2.9 & 5.2 & 4.0 \\
& annealed $400{ }^{\circ} \mathrm{C}$ & 1.0 & 2.3 & 1.6 \\
& annealed $550{ }^{\circ} \mathrm{C}$ & 1.0 & 2.8 & 1.5 \\
\hline
\end{tabular}

(2) Particles larger than $50 \mathrm{~nm}$, which were mainly NbTiV rich, effectively block dislocations; i.e., during slip, the dislocations bow around this particles prior to cutting (Figure 10(a)). However, due to a low number density and a large interparticle spacing, their precipitation strengthening effect is low.

(3) Particles smaller than $12 \mathrm{~nm}$, which were mainly $\mathrm{Cu}$ rich, do not effectively block dislocations; i.e., during slip, the dislocations cut these particles without prior bowing around them (Figure 10(b)).

(4) Particles in the $12-$ to $50-\mathrm{nm}$ size range were observed to pin dislocations; i.e., dislocation bowing around these particles occurred (Figure 10(c)).

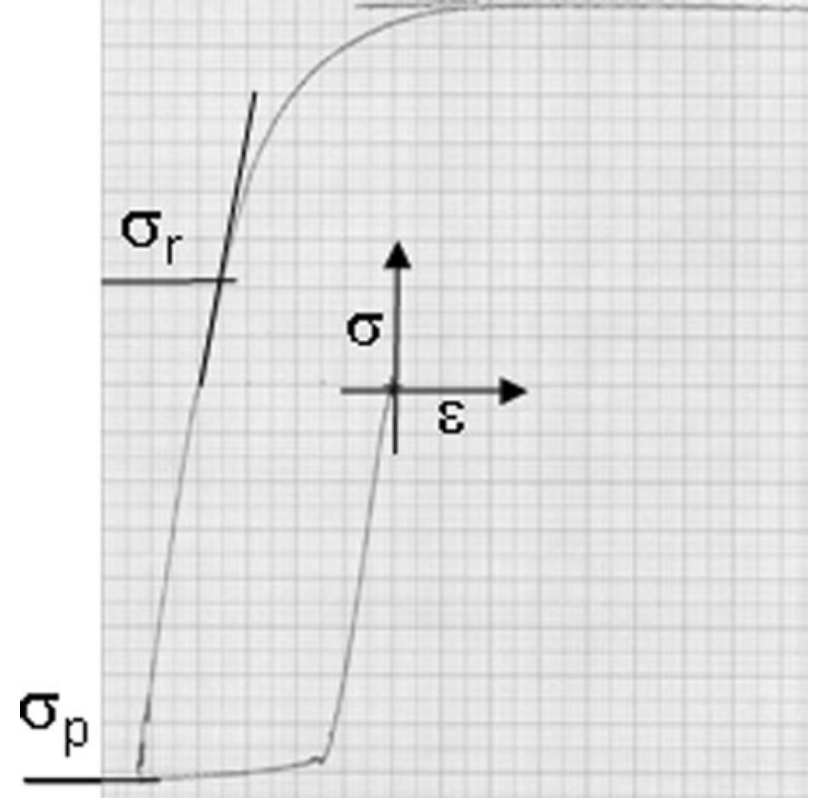

Fig. 8-Typical stress-strain curve during compression-tension testing (prestress is compression). 
In the 12- to 50-nm size range, the particle number density increases and the average interparticle spacing decreases with an increase in microalloying element content. Annealing of the $\mathrm{C}-\mathrm{Nb}-\mathrm{V}$ steel resulted in the 12- to $50-\mathrm{nm}$ particle number density increasing and the interparticle spacing decreasing, which is due to precipitation of new $\mathrm{Cu}$-rich particles (Table VI).

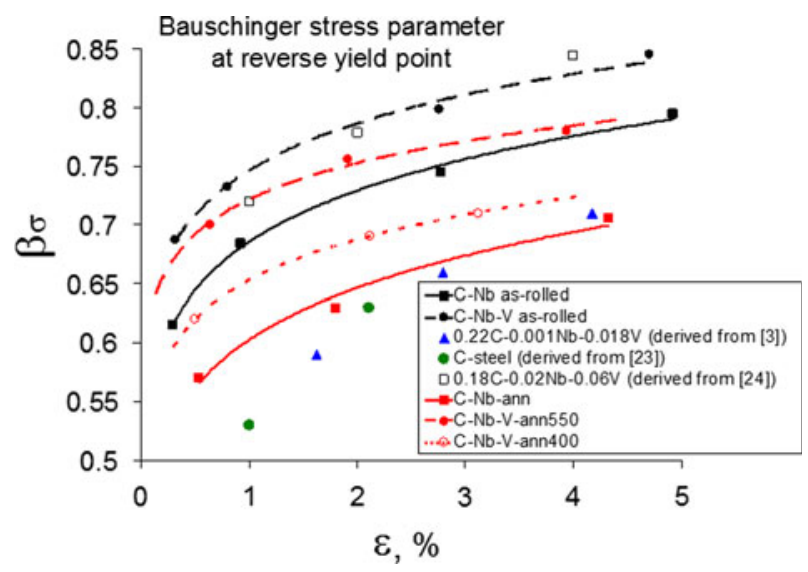

Fig. 9-The Bauschinger stress parameter measured for the reverse yield point (approximately 0.1 pct reverse strain).
With respect to the mechanical properties, the following aspects should be noted.

(1) "Large" particles, larger than 50-nm NbTiV rich in the studied steels, do not contribute significantly to the precipitation strengthening effect, because their number density is many times lower than that of the smaller than $50-\mathrm{nm}$ particles.

(2) "Small" particles, smaller than $12-\mathrm{nm} \mathrm{Cu}$ rich in the studied steels, do not contribute significantly to the precipitation strengthening effect, because they do not block dislocations strongly. However, as particle strength varies with particle chemistry, the effective particle diameter range can be expected to be dependent on particle chemistry.

(3) The number of dislocation-particle interactions will depend on the "dislocation length-interparticle spacing" ratio. Short dislocations may pass between widely set particles without little interaction.

Correlating the results of the microstructural investigation (Tables IV and VI) and the mechanical property study (Figure 9) for the same material conditions, it is possible to obtain a quantitative dependence of the Bauschinger stress parameter on dislocation density and particle number density within the effective particle size range of 12 to $50 \mathrm{~nm}$ (Figure 11). Quantitative contribution of the dislocation density to the reverse yield stress drop is observed to be approximately 4.6 times

Table V. The Microstructure-Mechanical Property Correlation for the Plate Midthickness Position

\begin{tabular}{|c|c|c|c|c|c|c|c|}
\hline \multirow[b]{3}{*}{ Steel Grade } & \multicolumn{5}{|c|}{ Microstructure Parameters } & \multirow{3}{*}{$\begin{array}{c}\text { Macrohardness, } \\
\mathrm{H}_{\mathrm{V}}\end{array}$} & \multirow{3}{*}{$\begin{array}{c}\text { Compressior } \\
\text { Yield stress, } \\
\mathrm{MPa}\end{array}$} \\
\hline & \multirow{2}{*}{$\begin{array}{l}\text { Grain } \\
\text { Size, } \mu \mathrm{m}\end{array}$} & \multirow{2}{*}{$\begin{array}{c}\text { Second Phase, } \\
\text { Pearlite } \\
\text { Pct }\end{array}$} & \multicolumn{2}{|c|}{$\begin{array}{l}\text { Particle number } \\
\text { Density, } \mu \mathrm{m}^{-3}\end{array}$} & \multirow{2}{*}{$\begin{array}{c}\text { Dislocation } \\
\text { Density, } \\
\times 10^{14} \mathrm{~m}^{-2}\end{array}$} & & \\
\hline & & & $50+\mathrm{nm}$ & $<50 \mathrm{~nm}$ & & & \\
\hline $\mathrm{C}-\mathrm{Nb}$ as-rolled & 3.0 & 13.1 & 0.44 & 86 & 2.3 & 193 & 480 \\
\hline $\mathrm{C}-\mathrm{Nb}$ ann. $550^{\circ} \mathrm{C}$ & 3.0 & 13.1 & 0.44 & 86 & 1.1 & 178 & 476 \\
\hline $\mathrm{C}-\mathrm{Nb}-\mathrm{V}$ as-rolled & 2.9 & 7.2 & 1.95 & 3856 & 4.0 & 209 & 487 \\
\hline $\mathrm{C}-\mathrm{Nb}-\mathrm{V}$ ann. $400^{\circ} \mathrm{C}$ & 2.9 & 7.2 & 1.95 & 8619 & 1.6 & 186 & 508 \\
\hline $\mathrm{C}-\mathrm{Nb}-\mathrm{V}$ ann. $550^{\circ} \mathrm{C}$ & 2.9 & 7.2 & 1.95 & 1419 & 1.5 & 187 & 499 \\
\hline
\end{tabular}
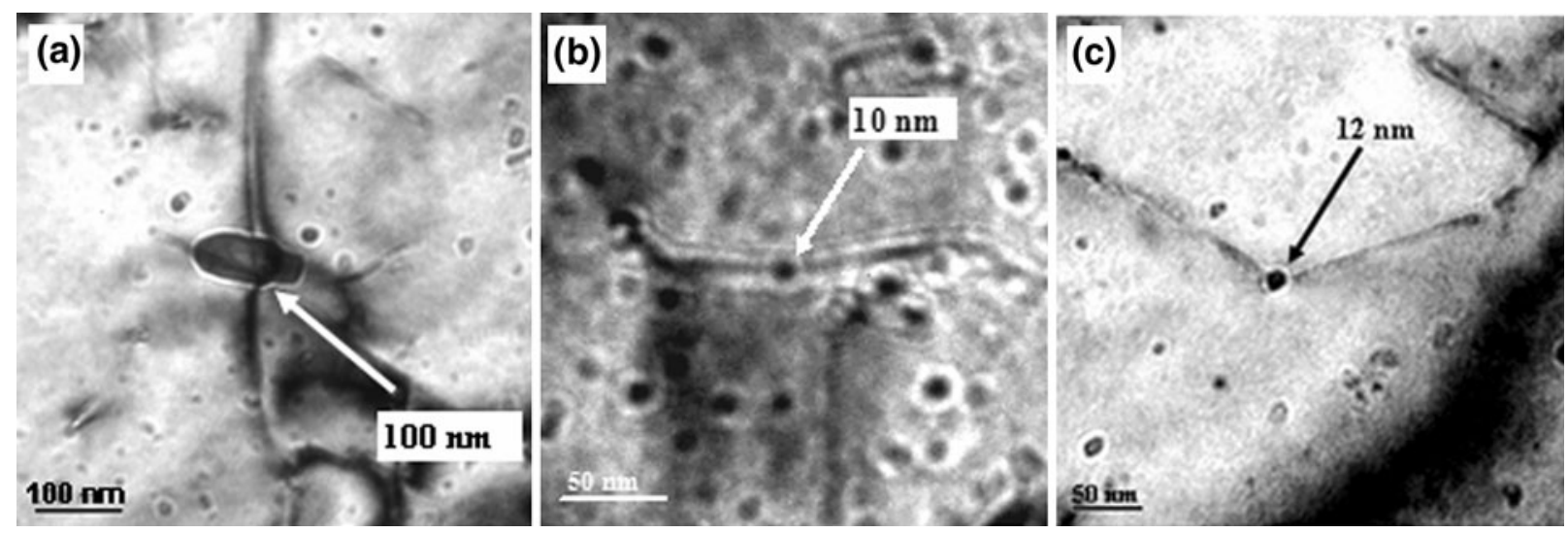

Fig. 10 -Dislocation-particle interaction sites with $a$ : (a) larger than $50-\mathrm{nm} \mathrm{NbTiV,}(b)$ smaller than $12-\mathrm{nm} \mathrm{Cu}$ rich, and $(c) 12$ to $50 \mathrm{~nm}(\mathrm{Cu}+$ NbTiV)-rich particle. 
Table VI. Measured Parameters for the 12 to 50 nm Particles at the Plate Midthickness

\begin{tabular}{lcccc}
\hline & & & \multicolumn{2}{c}{$\mathrm{C}-\mathrm{Nb}-\mathrm{V}$} \\
\cline { 3 - 5 } Parameter & $\begin{array}{c}\mathrm{C}-\mathrm{Nb} \\
\text { As-Rolled }\end{array}$ & As-Rolled & Annealed at $400{ }^{\circ} \mathrm{C}$ & Annealed at $550{ }^{\circ} \mathrm{C}$ \\
\hline Volume fraction & 0.00011 & 0.00076 & 0.00126 & 0.00374 \\
Average diameter, $\mathrm{nm}$ & 19.7 & 19.3 & 15.8 & 19.0 \\
Number density, $\mu \mathrm{m}^{-3}$ & 72 & 186 & 262 & 894 \\
Interparticle spacing in the micrograph plane, $\mu \mathrm{m}$ & $>0.4$ & 0.132 & 0.098 & 0.071 \\
\hline
\end{tabular}

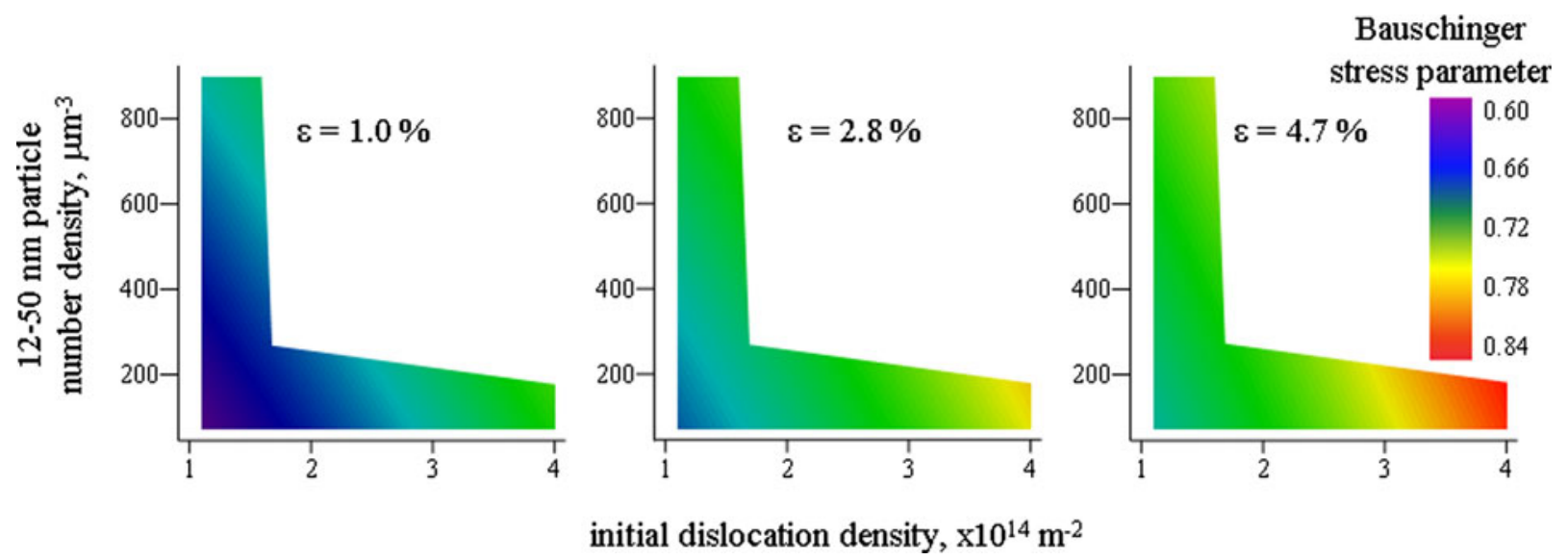

Fig. 11-The Bauschinger stress parameter dependence on dislocation density and particle number density for 1.0, 2.8, and 4.7 pct forward prestrain.

higher than the particle number density contribution, i.e., a 2.7 times increase in the dislocation density brings about the same Bauschinger stress parameter increase as 12.5 times increase in the particle number density.

\section{CONCLUSIONS}

In the present work, two steels, $\mathrm{Nb}$ - and $\mathrm{Nb}-\mathrm{V}$-microalloyed, in the as-rolled and annealed conditions have been characterized in terms of their dislocation densities and precipitate number densities. These parameters have been quantitatively related to the Bauschinger stress parameter determined by compression-tension testing. The main conclusions are as follows.

1. Dislocation density has been measured in the range of (1 to 4) $\times 10^{14} \mathrm{~m}^{-2}$, which corresponds to the earlier observed data for bcc structures.

2. Cu-rich particles smaller than $12 \mathrm{~nm}$ do not block dislocations effectively and can be disregarded as sources of precipitation strengthening.

3. $\mathrm{Cu}$-rich particles in the range of 12 to $50 \mathrm{~nm}$ block dislocations effectively and are the major sources of precipitation strengthening.

4. Nb-Ti-rich particles larger than $50 \mathrm{~nm}$ block dislocations effectively; however, their influence on precipitation strengthening via dislocation-particle interaction is insignificant due to their low number density and large interparticle spacing.
5. For the studied steel grades (average grain size 2.5 to $3.0 \mu \mathrm{m}, 12$ to $50 \mathrm{~nm}$ particle number, density 70 to $900 \mu \mathrm{m}^{-3}$, and dislocation density $1 \times 10^{14}$ to $4 \times 10^{14} \mathrm{~m}^{-2}$ ), the Bauschinger effect during reverse deformation was quantified by a dependence on particle number density, dislocation density, and forward prestrain (within 0.3 to 4.9 pct prestrain range). Quantitative contribution of the dislocation density to the Bauschinger effect was observed to be approximately 4.6 times higher than the particle number density contribution.

\section{ACKNOWLEDGMENTS}

The authors thank Corus plc for the provision of test material. Thanks are due to the Department of Metallurgy and Materials for the provision of research facilities at the University of Birmingham. One of the authors (AGK) is grateful to "The Universities, UK" for awarding a scholarship to carry out his research.

\section{REFERENCES}

1. P.S. Bate and D.V. Wilson: Acta Metall., 1986, vol. 34 (6), pp. 1097-1105.

2. L.M. Brown: Scripta Metall., 1977, vol. 11, pp. 127-31.

3. T.C. Harrison, R.T. Weiner, and G.D. Fearnehough: J. Iron Steel Inst., 1972, May, pp. 334-36. 
4. R.C. Ratnapuli and E.C. Rodrigues: Met. Technol., 1982, vol. 9, pp. $440-45$.

5. R.M. Jamieson and J.E. Hood: J. Iron Steel Inst., 1971, Jan., pp. 46-48.

6. K. Nakajima, W. Mizutani, T. Kikuma, and H. Matumoto: Trans. ISIJ, 1975, vol. 15, pp. 1-10.

7. J.P. Ormandy, M. Strangwood, and C.L. Davis: Mater. Sci. Technol., 2003, vol. 19, pp. 595-601.

8. K. Han, C.J. Van Tyne, and B.S. Levy: Metall. Mater. Trans. A, 2005, vol. 36A, pp. 2379-84.

9. A.G. Kostryzhev, M. Strangwood, and C.L. Davis: Mater. Technol.: Adv. Perform. Mater., 2007, vol. 22 (3), pp. 166-72.

10. A.G. Kostryzhev, M. Strangwood, and C.L. Davis: Ironmaking and Steelmaking, 2009, vol. 36 (3), pp. 186-92.

11. D. Williams and C.B. Carter: Transmission Electron Microscopy, II-Diffraction, Plenum Press, New York, NY, 1996, pp. 321-23.

12. C.L. Davis and M. Strangwood: J. Mater. Sci., 2002, vol. 37, pp. 1083-90.

13. M. Strangwood and C.L. Davis: Proc. 2nd Int. Conf. on "ThermoMechanical Simulation and Processing of Steels," Ranchi, India, Allied Publishers PVT. Ltd, New Delhi, India, 2008, pp. 453-63.
14. T. Gladman: The Physical Metallurgy of Microalloyed Steels, The Institute of Materials, Cambridge University Press, Cambridge, United Kingdom, 1997, pp. 97-99.

15. R. Rana, S.B. Singh, and O.N. Mohanty: Mater. Charact., 2008, vol. 59, pp. 969-74.

16. A. Ghosh, S. Das, S. Chatterjee, B. Mishra, and P. Ramachandra Rao: Mater. Sci. Eng. A, 2003, vol. 348, pp. 299-308.

17. S. Shanmugan, R.D.K. Misra, T. Mannering, D. Panda, and S.G. Jansto: Mater. Sci. Eng. A, 2006, vol. 437, pp. 436-45.

18. I. Madariaga, J.L. Romero, and I. Gutierrez: Metall. Mater. Trans. A, 1998, vol. 29A, pp. 1003-15.

19. B. Garbarz, J. Marcisz, and J. Wojtas: Mater. Chem. Phys., 2003, vol. 81, pp. 486-89.

20. F. Yin, T. Hanamura, O. Umezawa, and K. Nagai: Mater. Sci. Eng. A, 2003, vol. 354, pp. 31-39.

21. C.F. Robertson, K. Obrtlik, and B. Marini: J. Nucl. Mater., 2007, vol. 366, pp. $58-69$.

22. H.G. Hillenbrand, M. Graf, and C. Kalwa: Development and Production of High Strength Pipeline Steels, EUROPIPE GmbH, Ratingen, Germany, 2001, www.europipe.de.

23. A. Abel and H. Muir: Philos. Mag., 1972, vol. 26, pp. 489-504.

24. D.N. Williams: Metall. Trans. A, 1980, vol. 11A, pp. 1629-31. 